\title{
KEDUDUKAN ANAK ANGKAT DALAM HAK WARIS PADA MASYARAKAT ISLAM DI KOTA PALOPO (RELEVANSINYA PADA PENGADILAN AGAMA PALOPO)
}

\author{
Rahma Amir \\ IAIN Palopo \\ Jl. Agatis, Balandai, Kota Palopo, Sulawesi Selatan, Indonesia \\ E-mail: rahma_amir@iainpalopo.ac.id
}

\begin{abstract}
According to the law, Islamic Law Compilation (KHI) is a written law that used as specific guidelines for Muslims in resolving all legal issues including on the status of an adopted child. Therefore, this study aims to: 1). Knowing the position of adopted children with KHI and Civil Law, 2). Knowing the position of adopted children and their legacy rights. 3). Knowing the position adopted child and the adoptive parents, their legacy and guardian of the marriage.
\end{abstract}

Keywords: Adopted Child, Legacy Rights, Religious Court.

\begin{abstract}
Abstrak
Menurut hukum, Kompilasi Hukum Islam (KHI) merupakan hukum tertulis yang diberlakukan sebagai pedoman khusus bagi umat Islam dalam menyelesaikan segala permasalahan hukum termasuk tentang kedudukan anak angkat. Untuk itu, penelitian ini bertujuan untuk: 1). Mengetahui kedudukan anak angkat menurut KHI dan Hukum Perdata, 2). Mengetahui kedudukan anak angkat terhadap harta warisan. 3). Mengetahui kedudukan anak angkat dan orang tua angkat terhadap harta warisan dan wali nikah.
\end{abstract}

Kata Kunci: Anak Angkat, Hukum Kompilasi, Masyarakat Muslim, Hak Waris.

\section{PENDAHULUAN}

Anak angkat adalah anak yang haknya dialihkan dari lingkungan kekuasaan orang tua, wali yang sah atau orang lain yang bertanggung jawab atas perawatan, pendidikan dan membesarkan anak tersebut ke dalam lingkungan keluarga orang tua angkatnya berdasarkan putusan atau penetapan pengadilan. Anak angkat masuk kehidupan rumah tangga orang tua yang mengambilnya, sebagai anggota rumah tangganya, akan tetapi ia tidak berkedudukan sebagai anak kandung dengan fungsi untuk meneruskan turunan bapak angkatnya. Anak angkat di sini telah menjadi bagian keluarga dari orang tua yang mengangkatnya.

Sebagai bagian dari keluarga (anak), iapun berhak mendapatkan cinta dan kasih sayang orang tua seperti yang lainnya serta hak-hak dan kewajiban anak pada umumnya yang merupakan jaminan yang terdapat dalam ketetentuan perundangan yang berlaku. Orang tua angkat (wali) yang telah 
mengangkat seorang anak secara legal formal dan dengan perbuatan hukum tersebut telah mendapatkan hak asuh terhadap anak angkatnya, mereka (sebagai orang tua angkat/wali dengan anak) ${ }^{1}$ memiliki efek kausalitas pada hubungan hukum, hak dan kewajiban hukum yang melekat layaknya orang tua terhadap anaknya dalam komunitas keluarga.

Menurut Peraturan Pemerintah Nomor 54 Tahun 2007 pengertian Pengangkatan Anak adalah suatu perbuatan hukum yang mengalihkan seorang anak dari lingkungan kekuasaan orang tua, wali yang sah atau orang lain yang bertanggung jawab atas perawatan, pendidikan dan membesarkan anak tersebut ke dalam lingkungan keluarga orang tua angkat (Pasal 1 butir 2), sedangkan menurut Undang - undang Nomor 23 Tahun 2002, pengertian anak angkat adalah anak yang haknya dialihkan dari lingkungan kekuasaan keluarga orang tua, wali yang sah, atau orang lain yang bertanggung jawab atas perawatan, pendidikan dan pembesaran anak tersebut, ke lingkungan keluarga orang tua angkatnya berdasarkan putusan atau penetapan pengadilan. (Pasal 1 butir 9), tujuan Pengangkatan Anak adalah untuk tujuan kepentingan kebaikan anak angkat tersebut dalam rangka melindungi kesejahteraan anak dan perlindungan anak tersebut. Hal ini dapat dilihat dalam Pasal 2 Peraturan Pemerintah Nomor 54 Tahun 2007, ketentuan dalam Pasal 12 ayat (1) dan ayat (3) Undang-undang Kesejahteraan Anak dan juga sesuai dengan edaran Mahkamah Agung Nomor 6 Tahun 1983 (bagian IV. A.2.2.2.) kemudian Undang-undang Perlindungan Anak Pasal 39 ayat (1).

Sifat pengangkatan anak menurut peraturan perundang-undangan di Indonesia adalah sebagai berikut:

1. Pengangkatan anak adalah suatu perbuatan hukum. (Pasal 1 butir 2 Peraturan Pemerintah Nomor 54 Tahun 2007 tentang Pengangkatan Anak).

2. Pengangkatan anak adalah untuk melindungi kepentingan anak (Pasal 12 ayat (1) dan ayat (3) Undang-Undang Nomor 4 Tahun 1979 Tentang Kesejahteraan Anak); dan Pasal 39 ayat (1), (4) Undang-Undang Nomor 23 Tahun 2002 tentang Perlindungan Anak, Jo dan Pasal 5. Peraturan Pemerintah Nomor 54 Tahun 2007.

3. Pengangkatan anak harus menjaga kesamaan agama yang dianut oleh calon anak angkat dan calon orang tua angkat (Pasal 39 ayat (3), Pasal 19 butir d, Pasal 42, Pasal 43 Undang-undang Nomor 23 Tahun 2002 Jo. Pasal 3 Peraturan Pemerintah Nomor 54 Tahun 2007)

4. Pengangkatan anak tidak memutuskan hubungan darah antara anak dengan orang tua kandungnya (Penjelasan Pasal 12 ayat (1), UndangUndang Nomor 4 Tahun 1979: Pasal 39 ayat (2) Undang-Undang Nomor

\footnotetext{
${ }^{1}$ Hukum pengambilan anak angkat menurut Islam berlainan dari amalan dan adat pengambilan anak angkat menurut hukum Barat. Bertentangan dengan apa yang berlaku di dunia Barat, seorang anak angkat tidak meninggalkan keluarga biologis mereka (kecuali jika tidak diketahui) untuk memasuki keluarga yang mengasuh mereka. Bentuk pengambilan anak angkat ini dalam Bahasa Arab disebut kafala. Sebagai contoh bahwa bapak baru mereka tidak boleh menamakan anak lelaki itu dengan nama bapak angkatnya, dan bahwa anak itu dikirakan bukan Mahram. Ini dapat juga disamakan dengan anak yang menyusu pada ibu angkatnya dalam dua tahun yang pertama kehidupannya. Soerjono Soekanto dan Soleman B. Taneko, Hukum Adat Indonesia, Jakarta: PT. Rajawali, 1983, h. 108;
} 
23 Tahun 2002: Jo. Pasal 4 Peraturan Pemerintah Nomor 54 Tahun 2007). Dari segi hukum ini menimbulkan konsekensi sebagai berikut: Pertama, Berlaku larangan perkawinan karna hubungan darah sebagaimana dimaksud dalam Pasal 8 Undang-undang nomor 1 Tahun 1974: (a) berhubungan darah dalan garis keturunan lurus ke bawah atau ke atas; (b) berhubungan darah dalam garis keturunan menyamping yaitu antara saudara, antara seorang dengan seorang saudara orang tua dan antara seorang dengan saudara neneknya; (c) berhubungan semenda, yaitu mertua, anak tiri, menantu dan ibu/bapak tiri; (d) berhubungan susuan, anak susuan, saudara dan bibi/paman susuan; (e) berhubungan saudara dengan istri atau sebagai bibi atau kemenakan dari istri, dalam hal seorang suami beristri lebih dari seorang; (f) yang mempunyai hubungan yang oleh agamanya atau peraturan lain yang berlaku dilarang kawin (Undangundang No. 1 Tahun 1974 tentang Perkawinan.) Kedua, Tindak-tindak pidana yang ditentukan dalam Pasal 221 ayat (2), (menyembunyikan keluarga yang melakukan kejahatan), Pasal 294 ayat (1), Pasal 295 dan Pasal 356 (penganiayaan dalam keluarga) Kitab Undang-undang Hukum Pidana (KUHP). Ketiga, pembuktian dengan saksi dalam Pasal 145 dan 146 Reglement Acara Perdata Indonesia yang diperbarui (HIR), serta Pasal 168 Kitab Undang-undang Hukum Acara Pidana (KUHAP). tentang hubungan saksi dengan para pihak karena keluarga. Keempat, kewajiban terbuka kepada anak angkat tentang asal-usul dan orang tua asalnya (UU Perlindungan Anak : Pasal 6 ayat (1) berserta penjelasaannya, Pasal 40 dan Nomor 54 Tahun 2007 Tentang Pelaksanaan Pengangkatan Anak.

Berdasarkan uraian yang sesuai dengan Surat Edaran Mahkamah Agung RI No.6/83 yang mengatur tentang cara mengadopsi anak menyatakan bahwa untuk mengadopsi anak harus terlebih dahulu mengajukan permohonan pengesahan/pengangkatan kepada Pengadilan Negeri di tempat anak yang akan diangkat itu berada. Setelah permohonan disetujui Pengadilan, maka Salinan yang telah diperoleh ini harus dibawa ke kantor Catatan Sipil untuk menambahkan keterangan dalam akte kelahirannya. Sehingga dalam akte tersebut dinyatakan bahwa anak tersebut telah diadopsi dan di dalam Akta Kelahiran tersebut disamping tertulis Nama Kedua Orang Tuanya juga disebutkan pula nama orang tua angkatnya.

Perihal pengangkatan anak atau adopsi ini memiliki dua dimensi, yaitu dimensi sosial kemasyarakatan yang memiliki nilai membantu sesama umat manusia dan dimensi hukum yang berimplikasi pada pola pengaturan antara anak angkat, orang tua angkat dan orang tua kandungnya. Ketiga pilar inilah yang dalam dimensi hukum memiliki implikasi yang beragam. ${ }^{2}$

Pada masa Jahiliyah, pengangkatan anak merupakan hal yang istimewa, karena masyarakat jahiliyah pada saat itu menghukumi anak angkat sama dengan anak kandung sendiri. Terlebih lagi bagi anak angkat yang berjenis kelamin laki-laki, maka akan lebih mendapatkan tempat terhormat dibanding anak angkat yang berjenis kelamin perempuan. Istilah tabanni di zaman ini,

2 Muderis Zaini, Adopsi Suatu Tinjauan Dari Tiga Sistem Hukum (Jakarta: Sinar Grafika, 1995), 19. 
bisa menjelaskan tentang supremasi anak angkat, mereka menetapkan hukum putusnya hubungan nasab anak angkat dengan orang tua kandungnya untuk kemudian dihubungkan kepada orang tua angkatnya. ${ }^{3}$ Munculnya perbedaan perspektif, terutama hukum Islam dan hukum Perdata yang berlaku di Indonesia dalam memandang kedudukan anak angkat dan implikasinya terhadap perkara kewarisan menjadi hal yang menarik untuk diteliti. Secara sosiologis, fenomena pengangkatan anak atau adopsi telah memberikan makna tersendiri. Fenomena berupa adanya peralihan tanggung jawab dengan berbagai motivasi dari orang tua kandung kepada orang tua angkat, untuk mendidik dan membesarkan anak angkat. Di pihak lain, perbuatan tersebut telah melahirkan beberapa ketentuan hukum baru, terutama yang berhubungan dengan ketentuan pewarisan. Dalam UndangUndang Nomor 1 Tahun 1974 tidak diatur tentang masalah adopsi atau lembaga pengangkatan anak. Tetapi dalam hukum adat lembaga pengangkatan anak sudah dikenal sejak lama. Mengenai pengangkatan anak menurut hukum adat Indonesia, lebih banyak didasarkan pada pertalian darah dan tata cara menurut hukum adat dan kebiasaan masyarakat setempat.

Berdasarkan uraian tersebut, artikel ini mencoba mengkaji tentang: (1). Bagaimana Pandangan hukum Islam dan hukum Perdata di Indonesia terhadap kedudukan anak angkat?, (2). Bagaimana status anak angkat dalam kewarisan pada konteks masyarakat kota Palopo relevansinya di Pengadilan Agama?

\section{PENGANGKATAN ANAK}

Mempunyai anak merupakan tujuan dari adanya perkawinan untuk menyambung keturunan serta kelestarian harta kekayaan. Mempunyai anak adalah kebanggaan dalam keluarga. Namun, demikian tujuan tersebut terkadang tidak dapat tercapai sesuai dengan harapan. Beberapa pasangan ${ }^{4}$ hidup, tidaklah sedikit dari mereka mengalami kesulitan dalam memperoleh keturunan. Sedang keinginan untuk mempunyai anak nampaknya begitu besar. sehingga kemudian di antara merekapun ada yang mengangkat anak.

Untuk menjelaskan pengertian anak angkat, penulis akan membedakannya dari dua sudut pandang yaitu pengertian secara bahasa (etimologi ) dan secara istilah (terminologi ). Dalam kamus Bahasa Indonesia dapat dijumpai arti anak angkat, yaitu anak orang lain yang diambil dan disahkan sebagai anaknya sendiri. Selanjutnya dalam bahasa Belanda dapat dijumpai kata adopt yang berarti anak seseorang untuk dijadikan sebagai anak kandungnya sendiri. ${ }^{5}$ Dalam bahasa Inggris dapat dijumpai kata adopt yang berarti "take a child into one's family and treat it as one's own".6Yang

\footnotetext{
${ }^{3}$ Ahmad Rofiq, Hukum Islam Di Indonesia (Jakarta: Raja Grafindo Persada, 1995), 362.

${ }^{4}$ Purwadarmita, Kamus Bahasa Indonesia (Jakarta: Balai Pustaka, 1976), 38.

5 Yan Pramadya Puspa, Kamus Hukum Belanda, Indoensia, Inggris (Semarang: Aneka, n.d.), 37.

${ }^{6}$ AS Hornby and EV Gatenbing, The Advencedn Learner's of Carent English (London: Oxford University, n.d.).
} 
dimaksud adalah mengambil anak dalam keluarga dan menganggapmya sebagai anak sendiri. Sedang dalam bahasa arab disebut 'tabbani', yang berarti mengambil anak angkat. ${ }^{7}$

Dari pengertian menurut bahasa, dapat diambil kesimpulan bahwa anak angkat adalah anak orang lain yang diangkat menjadi anak sendiri. Jadi penekanannya pada persamaan status anak angkat dari hasil pengangkatannya sebagai anak kandung. Sebagai Kerangka pikir:

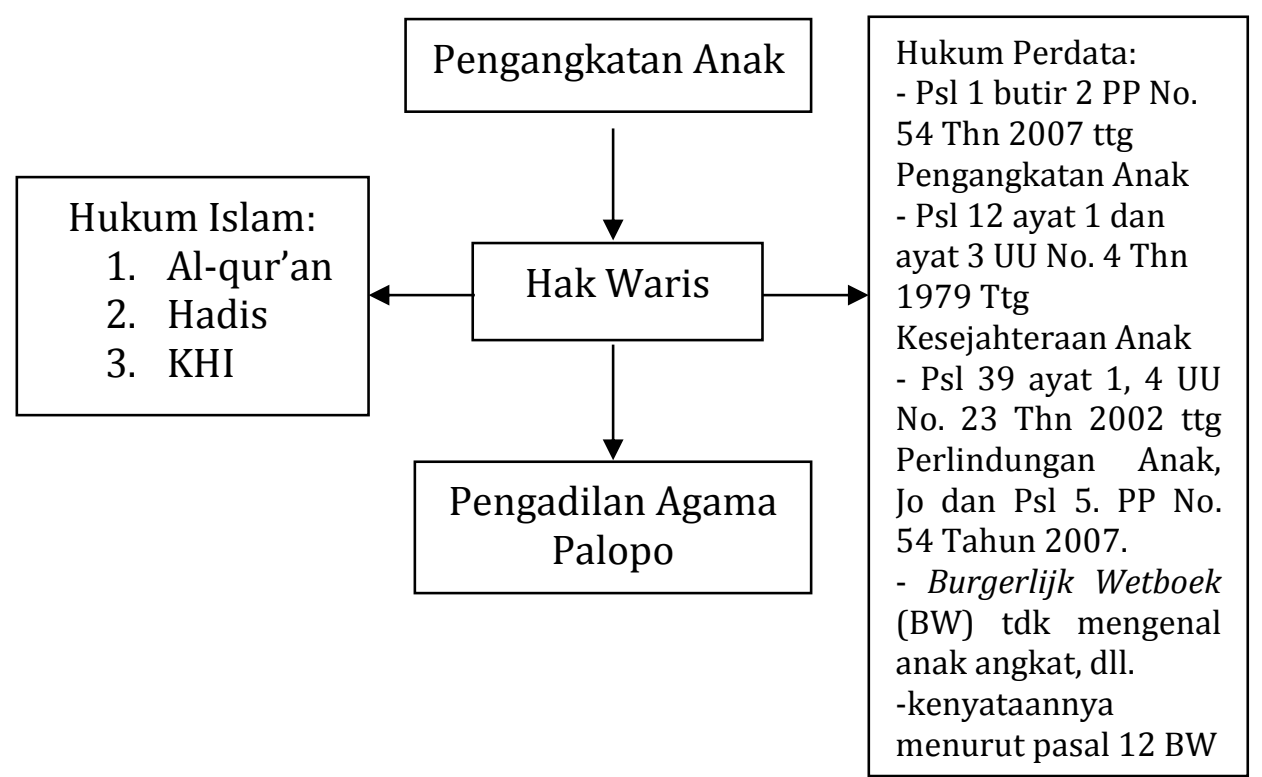

Gambar 1. Kedudukan Anak Angkat dalam Hak Waris pada Masyarakat Islam di Kota Palopo

\section{ANAK ANGKAT DALAM PERSOALAN STATUS KEWARISAN}

Pengangkatan anak bukanlah permasalahan yang baru. Sejak zaman jahiliyyah, pengangkatan anak telah dilakukan dengan cara dan motivasi berbeda-beda, sejalan dengan sistem dan peraturan hukum yang berlaku pada masyarakat yang bersangkutan.Pengangkatan anak terbagi dalam dua pengertian, yaitu: pertama, pengangkatan anak dalam arti luas. Ini menimbulkan hubungan nasab sehingga ada hak dan kewajiban selayaknya antara anak sendiri terhadap orang tua sendiri. kedua, ialah pengangkatan anak dalam arti terbatas. yakni pengangkatan anak orang lain ke dalam keluarga sendiri dan hubungan antara anak yang diangkat dan orang tua yang mengangkat hanya terbatas pada hubungan sosial saja. ${ }^{8}$

Di Indonesia, ada tiga sistem hukum yang berlaku dan mengatur permasalahan tentang pengangkatan anak. Ketiga sistem hukum itu adalah hukum Islam, hukum Adat dan hukum Barat. Untuk sementara pembahasan mengenai hukum Barat dan hukum Adat tidak kami sebutkan di sini, melainkan lebih dikonsentrasikan terhadap hukum Islam di Indonesia.

7 Mahmud Yunus, Kamus Arab-Indonesia (Jakarta: Yayasan Penyelenggara Penterjemah atau penafsiran Al-Qur'an, 1973), 73.

8 Soeroso R, Perbandingan Hukum Perdata (Jakarta: Sinar Grafika, 2001), 176. 
Hukum Islam sebagai satu pranata sosial memiliki dua fungsi; pertama, sebagai kontrol sosial dan kedua, sebagai nilai baru dan proses perubahan sosial. Jika yang pertama hukum Islam ditempatkan sebagai blue-print atau cetak biru Tuhan yang selain sebagai kontrol juga sekaligus sebagai social engineering terhadap keberadaan suatu komunitas masyarakat. Sementara yang kedua, hukum lebih merupakan produk sejarah yang dalam batas-batas tertentu diletakkan sebagai justifikasi terhadap tuntutan perubahan sosial, budaya, dan politik. Oleh karena itu, dalam konteks ini, hukum Islam dituntut akomodatif terhadap persoalan umat tanpa kehilangan prinsip-prinsip dasarnya. Sebab kalau tidak, besar kemungkinan hukum Islam akan mengalami kemandulan fungsi, atau meminjam istilah Abdurrahman Wahid, fosiliasi, bagi kepentingan umat. Karena itu apabila para pemikir hukum tidak memiliki kesanggupan atau keberanian untuk mereformulasi dan mengantisipasi setiap persoalan yang muncul dalam masyarakat dan mencari penyelesaian hukumnya, maka hukum Islam akan kehilangan aktualitasnya. Sehingga kemudian, sebagai realisasi dari semua itu dipandang perlu untuk diadakan pembaharuan Hukum Islam seperti telah diwujudkan dalam bentuk Kompilasi Hukum Islam atau dikenal KHI.

KHI Sesuai Inpres no.1 Tahun 1991 sebagaimana termaktub dalam dictumnya adalah perintah kepada Menteri Agama untuk menyebarluaskan Kompilasi Hukum Islam. ${ }^{9}$ Tujuannya ialah untuk digunakan oleh Instansi pemerintah dan masyarakat yang memerlukannya. Sementara itu, hukum adat atas kedudukannya dalam tata hukum nasional Indonesia merupakan hukum tidak tertulis yang berlaku sepanjang tidak menghambat terbentuknya masyarakat sosialis Indonesia dan menjadi pengaturpengatur hidup bermasyarakat. ${ }^{10}$ Di dalam hukum adat terdapat peraturan-peraturan hukum yang mengatur tentang berbagai masalah, termasuk mengenai pengangkatan anak. Anak angkat, di dalam hukum adat diartikan sebagai suatu ikatan sosial yang sama dengan ikatan kewangsaan biologis. ${ }^{11}$ Anak angkat dalam hukum adat mendapat kedudukan yang hampir sama dengan anak sendiri, yaitu dalam hal kewarisan dan perkawinan. Namun sebaliknya, dalam hukum Islam tidak demikian. Hukum Islam secara tegas melarang adanya pengangkatan anak yang mengakibatkan hubungan nasab antara anak angkat dengan orang tua angkat dan tidak pula menyebabkan hak waris. Hal ini diterangkan dalam QS. Al-Ahzāb/33:4 - 6:

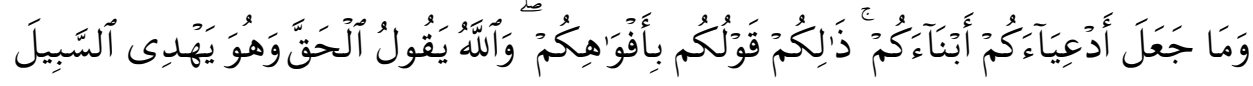

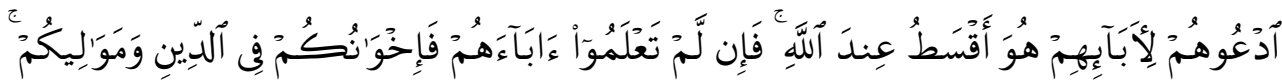

Dalam KHI disebutkan bahwa anak angkat adalah anak yang dalam hal pemeliharaan untuk hidupnya sehari-hari, biaya pendidikan dan sebagainya beralih tanggung jawab dari orang tua asal kepada orang tua angkatnya

9 Marzuki Wahid and Rumadi, Fiqh Mazhab Negara, Kritik Atas Hukum Islam Di Indonesia, 1st ed. (Yogyakarta: LKIS, 2001), 165.

10 Soerojo Wignjodipoero, Pengantar Dan Asas-Asas Hukum Adat (Jakarta: TP. Gunung Agung, 1995), 64-65.

11 Iman Sudiyat, Hukum Adat Sketsa Asas, 2nd ed. (Yogyakarta: Liberty, 1981), 12. 
berdasarkan putusan Pengadilan. Pengangkatan anak yang dimaksud bertujuan untuk menolong atau sekedar meringankan beban hidup bagi orang tua kandung. Sedang, pengangkatan anak juga sering dilakukan dengan tujuan untuk meneruskan keturunan bilamana dalam suatu perkawinan tidak memperoleh keturunan. Ada pula yang bertujuan sebagai pancingan, dengan mengangkat anak, keluarga tersebut akan dikaruniai anak kandung sendiri. Disamping itu ada yang disebabkan oleh rasa belas kasihan terhadap anak yang menjadi yatim piatu atau disebabkan oleh keadaan orang tuanya yang tidak mampu untuk memberi nafkah. Keadaan demikian, kemudian berlanjut pada permasalahan mengenai pemeliharaan harta kekayaan (harta warisan) baik dari orang tua angkat maupun orang tua asal (kandung). Sedang cara untuk meneruskan pemeliharaan harta kekayaan inipun dapat dilakukan melalui berbagai jalur sesuai dengan tujuan semula.

Hal-hal tersebut di atas, lebih jauh makna filosofis yang terkandung dari adanya pengangkatan anak yang karena keberadaannya, dalam Kompilasi Hukum Islam memberikan hak kepada anak angkat untuk mendapatkan harta dari orang tua angkat. Menurut Hukum Islam, anak angkat tidak dapat diakui untuk bisa dijadikan dasar dan sebab mewarisi, karena prinsip pokok dalam kewarisan Islam adalah hubungan darah/nasab/ keturunan. ${ }^{12}$ Dengan kata lain bahwa peristiwa pegangkatan anak menurut hukum kawarisan Islam, tidak membawa pengaruh hukum terhadap status anak angkat, yakni bila bukan merupakan anak sendiri, tidak dapat mewarisi dari orang yang setelah mengangkat anak tersebut.

Hal ini, tentunya akan menimbulkan masalah dikemudian hari apabila dalam hal warisan tersebut tidak dipahami oleh anak angkat, dikarenakan menurut hukum Islam, anak angkat tidak berhak mendapatkan pembagian harta warisan dari orang tua angkatnya, maka sebagai solusinya menurut Kompilasi Hukum Islam adalah dengan jalan pemberian "Wasiat Wajibah" sebanyak-banyaknya $1 / 3$ (sepertiga) harta warisan orang tua angkatnya. Sebagaimana telah diatur di dalam Kompilasi Hukum Islam Pasal 209 ayat 2 yang berbunyi : "Terhadap anak angkat yang tidak menerima wasiat maka diberi wasiat wajibah sebanyak-banyaknya $1 / 3$ dari harta warisan orang tua angkatnya". Permasalahan pengangkatan anak dan pembagian harta warisan menurut Kompilasi Hukum Islam tersebut diatas menarik bagi penulis untuk membahasnya.

Menurut ketentuan umum dalam Kompilasi Hukum Islam Pasal 171 bahwa anak angkat adalah anak yang dalam hal pemeliharaan untuk hidupnya sehari-hari, biaya pendidikan dan sebagainya beralih tanggungjawabnya dari orang tua asal kepada orang tua angkatnya berdasarkan putusan pengadilan. ${ }^{13}$ Atas dasar pengertian tersebut jelaslah bahwa yang dilarang menurut Hukum Islam adalah pengangkatan anak sebagai anak kandung dalam segala hal. Dari sini terlihat adanya titik persilangan menurut ketentuan hukum adat, yang menghilangkan atau memutuskan kedudukan anak angkat dengan orang tua kandungnya sendiri.

12 Hilman Hadikusuma, Hukum Waris Adat (Bandung: Citra Aditya Bakri, 1990), 43.

13 Abdurrahman, Kompilasi Hukum Islam Di Indonesia (Jakarta: Akademi Presindo, n.d.), 34. 
Hal ini bersifat prinsip dalam lembaga Adopsi karena adanya ketentuan yang menghilangkan hak-hak ayah kandung dan dapat merombak ketentuanketentuan mengenai waris. Berdasarkan uraian tersebut diatas, maka sudah selayaknya apabila ada suatu cara untuk menjembatani masalah anak angkat, sehingga anak angkat dapat dipelihara dengan baik dan dapat terjamin masa depannya, khususnya yang berkaitan dengan bagian waris anak angkat yang bersangkutan.

Dengan demikian, adopsi yang dilarang menuntut ketentuan dalam hukum Islam adalah seperti dalam pengertian aslinya, yakni menurut versi Hukum Barat bahwa mengangkat anak secara mutlak. Dalam hal ini adalah, memasukkan anak yang diketahuinya sebagai anak orang lain kedalam keluarganya yang tidak ada pertalian nasab kepada dirinya sebagai anak sendiri, seperti hak menerima warisan sepeninggalnya dan larangan kawin dengan keluarganya. ${ }^{14}$

Di dalam hukum waris Islam telah diatur secara rinci hal-hal yang menyangkut peralihan harta warisan dari seorang pewaris kepada ahli waris. ${ }^{15}$ Proses peralihan semacam itu dikenal dengan "Fara'id" yaitu ilmu tentang pembagian pusaka atau ilmu tentang ketentuan-ketentuan pusaka yang menjadi bagian ahli waris. Secara teoritis, warisan memiliki beberapa unsur yaitu pewaris, ahli waris dan harta warisan, yang ketiganya memiliki aturan-aturan tertentu yang mendasar.

Ditinjau dari sudut hukum kewarisan yang merupakan salah satu bagian dari hukum perorangan dan kekeluargaan, masalah waris pada umumnya berpokok pangkal pada sistem menarik garis keturunan, yaitu matrilineal yang menghubungkan keturunannya kepada garis ibu, patrilineal

14 R Wirjono Projodikoro, Hukum Warisan Di Indonesia (Bandung: Sumur Bandung, 1980), para. Kedudukan anak angkat dalam hal kewarisan menjadi gugur. Karena Islam membatasi sebab-sebab mempusakai itu hanya ber dasarkan keturunan, kebapakan, keibuan, perjodohan, persaudaraan, dan kekerabatan. Faturrahman, Ilmu Waris. Studi mengenai perkara kewarisan yang menjadi bagian dari materi hukum perdata di Indonesia telah banyak dilakukan oleh kalangan sarjana muslim, terlebih lagi hubungannya dengan kewarisan Islam. Namun demikian, penelitian kalangan sarjana yang menulis tentang status kewarisan anak angkat masih dipandang minim. Setidaknya literatur yang berhubungan dengan tema penelitian ini adalah karya R. Wirjono Projodikoro, Muderis Zaini, Pagar dan beberapa penulis lainnya. Sebagai seorang yang dibesarkan dalam tradisi pemikiran positivistik, R. Wirjono Projodikoro mengungkapkan bahwa masalah kewarisan merupakan masalah yang berkaitan dengan apa dan bagaimana hak-hak maupun kewajiban-kewajiban tentang kekayaan seseorang yang pada waktu ia meninggal dunia akan beralih kepada orang lain yang masih hidup Dengan pendekatan normatif, R. Wirjono Projodikoro menggaris bawahi bahwa terdapat perbedaan antara adopsi di antara orang-orang Tionghoa dan pengangkatan anak menurut hukum perdata bagi orang-orang Indonesia asli, yaitu perihal hubungan hukum antara anak angkat dan orang tuanya sendiri. Meski dengan berani dia mengatakan bahwa Burgerlijk Wetboek (BW) tidak mengenal anak angkat, dalam kenyataannya menurut pasal 12 BW, anak angkat itu dapat disamakan dengan seorang anak kandung. Adanya ketidak konsistenan inilah yang mempertanyakan secara epistemologis mengenai akar kesejarahan hukum kewarisan bagi anak angkat.

15 Sudarsono, Hukum Waris Dan Sistem Bilateral (Jakarta: Rineka Cipta, 1994), para. Dalam kewarisan Islam, ada empat prinsip pokok yaitu pertama, prinsip yang berkaitan dengan anak-anak, bapak dan ibu dari pewaris; kedua, prinsip mengenai suami-istri, saudara laki-laki dan saudara perempuan; ketiga, prinsip yang menyangkut mawāli dan keempat, prinsip yang berkaitan dengan masalah kalālah. 
yang hanya menghubungkan keturunan kepada bapak dan bilateral atau parental, yang menghubungkan keturunannya kepada bapak atau ibu, oleh karena sebuah keluarga telah melahirkan satuan-satuan kekeluargaan yang besar. ${ }^{16}$ Pengertian tersebut diatas sama dengan pengertian yang ada dalam fikih Indonesia (KHI ) sebagaimana dijelaskan dalam Pasal 1 huruf (g) yaitu : Suatu kegiatan mengasuh, memelihara dan mendidik anak hingga dewasa atau mampu berdiri sendiri. ${ }^{17}$

Oleh karena itu anak angkat bukan sebagai anak pribadi menurut syari'at Islam dan tidak ada ketetapan sedikitpun menurut syariat Islam kalau mengambil standar hukum Islam untuk membenarkannya. Sedangkan pengertian menurut Mahmud Saltut tersebut sama persis menurut hukum Barat $^{18}$ yang arahnya lebih menekankan kepada memasukkkan anak yang diketahui sebagai anak orang lain ke dalam keluarganya dengan mendapat status dan fungsi yang sama dengan anak kandung.

\section{ANAK ANGKAT DALAM PERSOALAN STATUS KEWARISAN}

Pada kalangan orang muslim, pengangkatan anak telah diatur dalam QS. al-Ahzab 4 dan 5. Sedangkan menurut Kompilasi Hukum Islam (KHI) pasal 171 huruf (h) menyatakan: "anak angkat adalah anak yang dalam pemeliharaannya untuk hidupnya sehari-hari, biaya pendidikan dan sebagainya beralih tanggungjawab dari orang tua asal kepada orang tua angkatnya berdasarkan Putusan Pengadilan".19 Menurut ketentuan hukum Islam anak angkat tidak mewaris, kemudian nilai pihak anak angkat adalah sosok yang mempunyai pertalian hubungan kemanusiaan yang bersifat khusus dalam soal kedekatan dan saling membantu serta penempatan statusnya dalam keluarga orang tua angkatnya sebagaimana layaknya keluarga sendiri. Dengan demikian anak angkat tidak termasuk golongan ahli waris, maka dengan sendirinya anak angkat tersebut tidak akan memperoleh harta warisan dari orang tua angkatnya yang telah meninggal terlebih dahulu. Oleh karena itu untuk melindungi hak-hak anak angkat dan orang tua angkat Kompilasi Hukum Islam memberi kepastian hukum berupa wasiat wajibah sebagaimana telah diatur dalam Pasal 209 KHI ayat ( 1 dan 2), yaitu:

1. Harta peninggalan anak angkat dibagi berdasarkan Pasal 176 sampai 193, sedangkan terhadap orangtua angkat yang tidak menerima wasiat diberi wasiat wajibah, sebanyak-banyaknya $1 / 3$ dari harta warisan anak angkatnya.

16 Hazairin, Hukum Kewarisan Bilateral Menurut Al-Qur'an Dan Hadis (Jakarta: Tintamas, 1983), 11.

${ }^{17}$ Abdurrahman, Kompilasi Hukum Islam Di Indonesia, 3.

${ }_{18}$ Dengan demikian, adopsi yang dilarang menuntut ketentuan dalam hukum Islam adalah seperti dalam pengertian aslinya, yakni menurut versi Hukum barat yaitu mengangkat anak secara mutlak. Dalam hal ini adalah, memasukkan anak yang diketahuinya sebagai anak orang lain kedalam keluarganya yang tidak ada pertalian nasab kepada dirinya sebagai anak sendiri, seperti hak menerima warisan sepeninggalnya dan larangan kawin dengan keluarganya.

19 Himpunan Perundang-Undangan Dalam Lingkungan Pengadilan Agama (Dirbinbapera Depag, 2001), 360. 


\section{2 | Rahma Amir}

2. Terhadap anak angkat yang tidak menerima wasiat, diberi wasiat wajibah sebanyak-banyaknya 1/3 dari harta warisan orangtua angkatnya

Menurut Soeparman Usman wasiat wajibah dapat didefinisikan sebagai wasiat yang pelaksanaannya tidak dipengaruhi atau tidak bergantung kepada kehendak orang yang meninggal dunia. Wasiat ini tetap dilkasanakan, baik diucapkan, dihekendaki maupun tidak dikehendaki oleh orang yang meninggal dunia jadi pelaksanaan wasiat tersebut tidak memerlukan bukti bahwa wasiat tersbut diucapkan, dituliskan, atau dikehendaki, tetapi pelaksanaannya didasarkan kepada alasan-alasan hukum yang membenarkan bahwa wasiat tersebut harus dilaksanakan. ${ }^{20}$

Adapun dalam Undang-Undang Nomor 1 Tahun 1974 tidak diatur tentang masalah adopsi atau lembaga pengangkatan anak. Tetapi dalam hukum adat lembaga pengangkatan anak sudah dikenal sejak lama. Mengenai pengangkatan anak menurut hukum adat Indonesia, lebih banyak didasarkan pada pertalian darah dan tata cara menurut hukum adat dan kebiasaan masyarakat setempat. Misalnya di Jawa, orang lebih suka mengangkat anak dari kalangan keluarga sendiri. Pengangkatan anak menurut hukum adat supaya dianggap sah harus dilaksanakan dengan upacara-upacara tertentu dan dengan dihadiri kepala desa setempat serta disaksikan khalayak ramai, agar menjadi jelas dan statusnya menjadi terang bagi anggota keluarga. Hal ini sebagaimana disebut dalam Yurisprudensi Mahkamah Agung Tanggal 19 November 1975 No.696/K/SIUP/1975 yang menetapkan: "Bila belum disiar, belum memenuhi syarat sebagai anak angkat yang sah." Dalam perkembangan selanjutnya, orang tidak membatasi dari anak kalangan keluarga sendiri saja, tetapi juga pada anak-anak yang lain yang terdapat pada panti-panti asuhan, penampungan bayi dan sebagainya.

Meskipun adopsi belum diatur secara tegas dalam perundangundangan yang bersifat nasional, dalam prakteknya adopsi itu sering terjadi di masyarakat. Oleh sebab itu harus diusahakan adanya suatu peraturan yang mengatur dan menjamin pelaksanaan anak angkat. Walaupun pada dasarnya pengangkatan anak merupakan masalah keluarga, namun akhirnya menjelma menjadi problema masyarakat dan negara, sehingga menimbulkan permasalahan-permasalahan tertentu, misalnya kasus penculikan anak dan jual beli anak, seperti diatur dalam KUHP Pasal 328 yang mengatur masalah penculikan dan diancam dengan pidana penjara paling lama dua belas tahun.

Secara umum pengangkatan anak menurut hukum adalah pengalihan anak terhadap orang tua angkat dari orang tua kandung secara keseluruhan dan dilakukan menurut adat setempat agar sah. Jadi orang tua kandung sudah lepas tangan terhadap anak itu, dan tanggung jawab beralih kepada orang yang mengangkatnya. ${ }^{21}$ Namun menurut hukum Islam pada prinsipnya mengakui dan membenarkanpengangkatan anak dengan ketentuan tidak boleh membawa perubahan hukum dibidang nasab, wali mewali dan aris mewaris. Dasar hukumnya adalah Al Qur'an sebagaimana yang tertera dalam Surat al-Ahzab/4-5.

20 Soeparman Usman, Ikhtisar Hukum Waris Kitab Undanng-Undang Hukum Perdata (Bw) (Semarang: Darul Ulum Press, 1993), 70.

21 Soedaryo Soimin, Hukum Orang Dan Keluarga (Jakarta: Sinar Grafika, 1992), 42. 
Dalam perkembangannya, hukum Islam memperbolehkan pengangkatan anak asal tidak memutuskan hubungan darah dengan orang tua kandungnya, sehingga prinsip pengangkatan anak dalam hukum Islam hanya bersifat pengasuhan, pemberian kasih sayang dan pemberian pendidikan. M. Budiarto menyebutkan menurut hukum Islam pengangkatan anak hanya dapat dibenarkan apabila memenuhi ketentuan-ketentuan sebagai berikut:

1. Tidak memutuskan hubungan darah antara anak yang diangkat dengan orang tua kandung dan keluarganya.

2. Anak angkat tidak berkedudukan sebagai pewaris dari orang tua angkatnya, melainkan tetap sebagai pewaris dari orang tua kandungnya, demikian juga orang tua angkatnya berkedudukan sebagai pewaris dari anak angkatnya.

3. Anak angkat tidak boleh menggunakan nama orang tua angkatnya secara langsung, kecuali sekedar sebagai alamat atau tanda pengenal. diatas,

4. Orang tua angkatnya tidak bisa bertindak sebagai wali dalam perkawinan anak angkatnya. ${ }^{22}$

Hal tersebut di atas, menjadi permasalahan yang perlu dijawab secara jelas melalui pendekatan secara filosofis dengan mengungkapkan beberapa teori keadilan hukum, baik dalam KHI maupun hukum Islam. Di dalam hukum Islam terdapat asas keadilan dan keseimbangan. Keadilan merupakan nilai yang tidak dapat ditawar-tawar karena hanya dengan keadilanlah ada jaminan stabilitas hidup manusia. Keseimbangan, keserasian dan keselarasan sikap dan tingkah laku manusia yang hidup dalam masyarakat, terjelma dalam bentuk nilai-nilai, hak-hak dan kewajiban-kewajiban. Asas keadilan dan keseimbangan, mengandung arti bahwa harus senantiasa terdapat keseimbangan antara hak dan kewajiban; antara hak yang diperoleh seseorang dengan kewajiban yang harus ditunaikannya. Keadilan di dalam KHI menjadi titik yang terakhir untuk mendapatkan hakikat yang terdalam mengenai kedudukan anak angkat terhadap harta warisan seperti dalam permasalahannya.

\section{PERTIMBANGAN HUKUM DALAM PERMOHONAN PENGANGKATAN ANAK}

Kedudukan anak angkat adalah sebagai seorang anak yang dalam pemeliharaannya kehidupannya sehari-hari, biaya pendidikan dan sebagainya beralih tanggungjawabnya dari orang tua asal ke orang tua angkat, berdasarkan putusan Pengadilan. Akibat hukumnya, anak angkat tidak bernasab dan tidak sebagai ahli waris dari orang tua angkatnya, tetapi ia mewaris dengan jalan hak wasiat wajibah dengan ketentuan tidak melebihi $1 / 3$ dari harta warisan. Namun pada hakekatnya bagian ini terlalu besar, sehingga dalam kenyataan ada yang memberinya $1 / 8$ atau $1 / 10$ saja.

22 M Budiarto, Pengangkatan Anak Ditinjau Dari Segi Hukum (Jakarta: Akademika Presindo, 1985), 24-25. 


\section{4 | Rahma Amir}

Pertimbangan-Pertimbangan hukum yang dipergunakan oleh hakim Pengadilan Agama berdasarkan maslahah mursalah yaitu untuk kesejahteraan anak, pelengkap kebahagian orang tua angkat yang tidak mempunyai anak serta untuk membantu orang tua asal yang kurang mampu memelihara anak kandungnya tersebut.

Maslahat dapat digunakan dan dijadikan sumber penetapan hukum apabila :

1. Adanya kesesuaian antara maslahat yang dipandang sebagai sumber dalil yang berdiri sendiri dengan tujuan-tujuan syariah (maqasidu al-syari'ah)

2. Maslahat itu harus masuk akal, artinya bahwa maslahat mempunyai sifat yang sesuai dengan pemikiran yang rasional jika diajukan kepada kelompok rasionalis akan dapat diterima

3. Penggunaan dalil maslahat ini adalah dalam rangka menghilangkan kesulitan yang terjadi, dalam pengertian bahwa apabila maslahat diterima oleh akal tidak diambil, niscaya manusia akan mengalami kesulitan.

Hal ini sesuai dengan firman Allah dalam QS. al-Hajj/22:76 ;

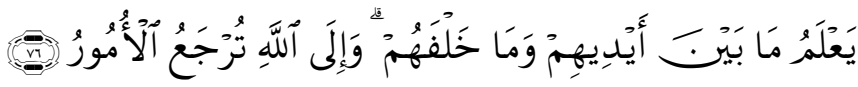

Terjemahnya :

"Dia sekali-kali tidak menjadikan untuk kamu dalam agama saat kesempitan".

Dalam hukum Islam ada perintah untuk menyelesaikan setiap permasalahan. Anak angkat, dalam kaitannya dengan harta warisan orang tua angkatnya, secara hukum tidak berhak menerima bagian. Dalam keadaan demikian syariat Islam membuka pintu wasiat bagi orang tua angkat untuk memberikan hartanya sebagian guna kelanjutan pemeliharaan hidupnya.

Menurut Kompilasi Hukum Islam (KHI) Pasal 209 menentukan wasiat wajibah:

1. Harta peninggalan anak angkat dibagi berdasarkan Pasal 176 sampai dengan Pasal 193, sedangkan terhadap orang tua angkat yang tidak menerima wasiat diberi wasiat wajibah, sebanyak-banyaknya 1/3 dari harta warisan anak angkatnya.

2. Terhadap anak angkat yang tidak menerima wasiat, diberi wasiat wajibah sebanyak-banyaknya $1 / 3$ dari harta warisan orangtua angkatnya.

Pada kalangan orang muslim, pengangkatan anak telah diatur dalam SQ. al-Ahzab ayat 4 - 5. Sedangkan menurut Kompilasi Hukum Islam (KHI) pasal 171 huruf ( $\mathrm{h}$ ) menyatakan: "anak angkat adalah anak yang dalam pemeliharaannya untuk hidupnya sehari-hari, biaya pendidikan dan sebagainya beralih tanggungjawab dari orang tua asal kepada orang tua angkatnya berdasarkan Putusan Pengadilan"23. Menurut ketentuan hukum Islam anak angkat tidak mewaris, kemudian nilai pihak anak angkat adalah sosok yang mempunyai pertalian hubungan kemanusiaan yang bersifat khusus dalam soal kedekatan dan saling membantu serta penempatan

${ }^{23}$ Himpunan Perundang-Undangan Dalam Lingkungan Pengadilan Agama, 340. 
statusnya dalam keluarga orang tua angkatnya sebagaimana layaknya keluarga sendiri.

Dengan demikian anak angkat tidak termasuk golongan ahli waris, maka dengan sendirinya anak angkat tersebut tidak akan memperoleh harta warisan dari orang tua angkatnya yang telah meninggal terlebih dahulu. Oleh karena itu untuk melindungi hak-hak anak angkat dan orang tua angkat Kompilasi Hukum Islam memberi kepastian hukum berupa wasiat wajibah sebagaimana telah diatur dalam Pasal 209 KHI Ayat ( 1 dan 2 ), yaitu :

1. Harta peninggalan anak angkat dibagi berdasarkan Pasal 176 sampai dengan Pasal 193, sedangkan terhadap orangtua angkat yang tidak menerima wasiat diberi wasiat wajibah, sebanyak-banyaknya $1 / 3$ dari harta warisan anak angkatnya.

2. Terhadap anak angkat yang tidak menerima wasiat, diberi wasiat wajibah sebanyak - banyaknya 1/3 dari harta warisan orangtua angkatnya

Menurut Soeparman Usman wasiat wajibah dapat didefinisikan sebagai wasiat yang pelaksanaannya tidak dipengaruhi atau tidak bergantung kepada kehendak orang yang meninggal dunia. Wasiat ini tetap dilkasanakan, baik diucapkan, dihekendaki maupun tidak dikehendaki oleh orang yang meninggal dunia jadi pelaksanaan wasiat tersebut tidak memerlukan bukti bahwa wasiat tersbut diucapkan, dituliskan, atau dikehendaki, tetapi pelaksanaannya didasarkan kepada alasan-alasan hukum yang membenarkan bahwa wasiat tersebut harus dilaksanakan. ${ }^{24}$

Adapun dalam Undang-Undang Nomor 1 Tahun 1974 tidak diatur tentang masalah adopsi atau lembaga pengangkatan anak. Tetapi dalam hukum adat lembaga pengangkatan anak sudah dikenal sejak lama. Mengenai pengangkatan anak menurut hukum adat Indonesia, lebih banyak didasarkan pada pertalian darah dan tata cara menurut hukum adat dan kebiasaan masyarakat setempat. Misalnya di Jawa, orang lebih suka mengangkat anak dari kalangan keluarga sendiri. Pengangkatan anak menurut hukum adat supaya dianggap sah harus dilaksanakan dengan upacara-upacara tertentu dan dengan dihadiri kepala desa setempat serta disaksikan khalayak ramai, agar menjadi jelas dan statusnya menjadi terang bagi anggota keluarga. Hal ini sebagaimana disebut dalam Yurisprudensi Mahkamah Agung Tanggal 19 November 1975 No.696/K/SIUP / 1975 yang menetapkan : "Bila belum disiar, belum memenuhi syarat sebagai anak angkat yang sah." Dalam perkembangan selanjutnya, orang tidak membatasi dari anak kalangan keluarga sendiri saja, tetapi juga pada anak-anak yang lain yang terdapat pada panti-panti asuhan, penampungan bayi dan sebagainya.

Meskipun adopsi belum diatur secara tegas dalam perundangundangan yang bersifat nasional, dalam prakteknya adopsi itu sering terjadi di masyarakat. Oleh sebab itu harus diusahakan adanya suatu peraturan yang mengatur dan menjamin pelaksanaan anak angkat. Walaupun pada dasarnya pengangkatan anak merupakan masalah keluarga, namun akhirnya menjelma menjadi problema masyarakat dan negara, sehingga menimbulkan

${ }^{24}$ Soeparman Usman, Ikhtisar Hukum Waris Kitab Undanng-Undang Hukum Perdata $(B w), 70$.

Vol 1, No.2, Oktober 2016 
permasalahan-permasalahan tertentu, misalnya kasus penculikan anak dan jual beli anak, seperti diatur dalam KUHP Pasal 328 yang mengatur masalah penculikan dan diancam dengan pidana penjara paling lama dua belas tahun.

Secara umum pengangkatan anak menurut hukum adalah pengalihan anak terhadap orang tua angkat dari orang tua kandung secara keseluruhan dan dilakukan menurut adat setempat agar sah. Jadi orang tua kandung sudah lepas tangan terhadap anak itu, dan tanggung jawab beralih kepada orang yang mengangkatnya. ${ }^{25}$ Namun menurut hukum Islam pada prinsipnya mengakui dan membenarkanpengangkatan anak dengan ketentuan tidak boleh membawa perubahan hukum dibidang nasab, wali mewali dan aris mewaris. Dasar hukumnya adalah Al Qur'an sebagaimana yang tertera dalam Surat al-Ahzab/4-5.

Dalam perkembangannya, hukum Islam memperbolehkan pengangkatan anak asal tidak memutuskan hubungan darah dengan orang tua kandungnya, sehingga prinsip pengangkatan anak dalam hukum Islam hanya bersifat pengasuhan, pemberian kasih sayang dan pemberian pendidikan. M. Budiarto menyebutkan menurut hukum Islam pengangkatan anak hanya dapat dibenarkan apabila memenuhi ketentuan-ketentuan sebagai berikut:

1. Tidak memutuskan hubungan darah antara anak yang diangkat dengan orang tua kandung dan keluarganya.

2. Anak angkat tidak berkedudukan sebagai pewaris orang tua angkatnya, melainkan tetap sebagai pewaris dari orang tua kandungnya, demikian juga orang tua angkatnya berkedudukan sebagai pewaris dari anak angkatnya.

3. Anak angkat tidak boleh menggunakan nama orang tua angkatnya secara langsung, kecuali sekedar sebagai alamat atau tanda pengenal. diatas,

4. Orang tua angkatnya tidak bisa bertindak sebagai wali dalam perkawinan anak angkatnya. ${ }^{26}$

Hal tersebut di atas, menjadi permasalahan yang perlu dijawab secara jelas melalui pendekatan secara filosofis dengan mengungkapkan beberapa teori keadilan hukum, baik dalam KHI maupun hukum Islam. Di dalam hukum Islam terdapat asas keadilan dan keseimbangan. Keadilan merupakan nilai yang tidak dapat ditawar-tawar karena hanya dengan keadilanlah ada jaminan stabilitas hidup manusia. Keseimbangan, keserasian dan keselarasan sikap dan tingkah laku manusia yang hidup dalam masyarakat, terjelma dalam bentuk nilai-nilai, hak-hak dan kewajiban-kewajiban. Asas keadilan dan keseimbangan, mengandung arti bahwa harus senantiasa terdapat keseimbangan antara hak dan kewajiban; antara hak yang diperoleh seseorang dengan kewajiban yang harus ditunaikannya. Keadilan di dalam KHI menjadi titik yang terakhir untuk mendapatkan hakikat yang terdalam mengenai kedudukan anak angkat terhadap harta warisan seperti dalam permasalahannya.

25 Soedaryo Soimin, Hukum Orang Dan Keluarga, 42.

26 M Budiarto, Pengangkatan Anak Ditinjau Dari Segi Hukum, 24-25. 


\section{HAK DAN KEWAJIBAN ANAK ANGKAT}

Terhadap anak angkat di Indonesia termasuk anak angkat bertujuan untuk menjamin terpenuhinya hak-hak anak agar dapat hidup tumbuh berkembang dan berpartisipasi secara optimal sesuai dengan harkat dan martabat kemanusiaan, serta mendapat perlindungan dari kekerasan dan diskriminasi, demi terwujudnya anak Indonesia yang berkualitas, berakhlak mulia dan sejahtera. Anak angkat dan anak-anak lain pada hakekatnya adalah amanah dan karunia Tuhan Yang Maha Esa yang dalam dirinya melekat hak-hak yang perlu dihormati dan dijunjung tinggi oleh orang tua angkatnya dan masyarakat pada umumnya, hak-hak anak angkat yang dimaksud adalah :

1. Berhak untuk dapat hidup, tumbuh, berkembang dan berpartisipasi secara wajar sesuai dengan harkat dan martabat kemanusiaan, serta mendapat perlindungan dari kekerasan dan diskriminasi.

2. Berhak atas suatu nama sebagai identitas diri dan status kewarganegaraan.

3. Berhak untuk beribadah menurut agamanya, berfikir dan berekspresi sesuai dengan tingkat kecerdasan dan usianya dalam bimbingan orang tuanya.

4. Berhak untuk mengetahui orang tuanya, dibesarkan dan diasuh orang tuanya sendiri.

5. Karena suatu sebab orang tuanya tidak dapat menjamin tumbuh kembang anak, atau anak dalam keadaan terlantar, maka anak tersebut berhak diasuh dan diangkat oleh orang tua lain sesuai dengan ketentuan peraturan perundang-undangan yang berlaku.

6. Berhak memperoleh pelayanan kesehatan dan jasmani sosial sesuai dengan kebutuhan fisik, mental, spiritual, dan sosial.

7. Berhak memperoleh pendidikan dan pengajaran dalam rangka pengembangan pribadinya dan tingkat kecerdasannya sesuai dengan minat dan bakatnya.

8. Khusus untuk anak yang menyandang cacat juga berhak memperoleh pendidikan luar biasa, sedangkan untuk anak yang mempunyai keunggulan juga berhak mendapatkan pendidikan khusus.

9. Setiap anak berhak untuk beristirahat dan memanfaatkan waktu luang, bergaul dengan anak yang sebaya, bermain dan berkreasi sesuai dengan minat, bakat dan tingkat kecerdasannya demi perkembangan diri.

10. Setiap anak berhak menyatakan dan didengar pendapatnya, menerima, mencari, dan memberikan informasi sesuai tingkat kecerdasan dan usianya demi pengembangan dirinya sesuai dengan nilai-nilai kesusilaan dan kepatutan.

11. Setiap anak yang dalam pengasuhan orang tua, wali atau pihak manapun yang bertanggung jawab atas pengasuhan, berhak mendapat perlindungan dari perlakuan: diskriminasi, eksploitasi, baik ekonomi maupun seksual, penelantaran, kekejaman, kekerasan, dan penganiayaan, dan ketidakadilan.

12. Setiap anak berhak untuk memperoleh perlindungan dari: penyalahgunaan dalam kegiatan politik, pelibatan dalam sengketa 
bersenjata, pelibatan dalam kerusuhan sosial, pelibatan dalam peristiwa yang mengandung unsur kekerasan, dan pelibatan dalam peperangan.

13. Setiap anak berhak memperoleh perlindungan dari sasaran penganiayaan, penyiksaan, atau penjatuhan hukuman yang tidak manusiawi. Setiap anak berhak untuk memperoleh kebebasan sesuai dengan hukum

14. Setiap anak yang menjadi korban atau pelaku kekerasan seksual atau yang berhadapan dengan hukum wajib dirahasiakan

15. Setiap anak yang menjadi korban atau pelaku tindak pidana berhak mendapatkan bantuan hukum dan bantuan lainnya. ${ }^{27}$

Disamping hak-hak yang dijamin oleh undang-undang tersebut, anakanak dan atau termasuk anak angkat memiliki kewajiban-kewajiban sebagai kewajiban asasi yang juga harus dilaksanakan seorang anak yaitu. bahwa setiap anak berkewajiban untuk :

1. menghormati orang tuanya, wali, dan guru

2. mencintai keluarga, dan menyayangi teman

3. mencintai tanah air dan Negara

4. menunaikan ibadah sesuai dengan ajaran agamanya

5. melaksanakan etika dan akhlak yang mulia. ${ }^{28}$

Dari uraian di atas dapat diambil kesimpulan bahwa orang tua berkewajiban menyampaikan atau memberikan pendidikan kepada anaknya, dalam soal ini Islam sangat mementingkan pendidikan yang dapat menanamkan jiwa tauhid pada diri anak. Dalam ketentuan hukum Islam, sebab-sebab untuk menerima warisan ada tiga ( 3 ), yaitu:

Pertama; hubungan kekerabatan ( al-qarabah ). Dalam ketentuan hukum jahiliyah, kekerabatan menjadi sebab mewarisi adalah terbatas pada laki-laki yang telah dewasa, kaum perempuan dan anak-anak tidak mendapat bagian. ${ }^{29}$ Islam datang untuk memperbarui dan merevisinya, kedudukan lakilaki dan perempuan termasuk di dalamnya anak-anak, bahkan bayi yang masih di dalam kandungan pun, mereka sama-sama diberi hak untuk dapat mewarisi, sepanjang hubungan kekerabatan jelas dan memperbolehkan. Artinya ada ketentuan bahwa kerabat yang dekat hubungannya, dapat menghalangi kerabat yang jauh. Adakalanya menghalangi (menghijab) secara keseluruhan, adakalanya menghalangi itu hanya sekedar mengurangi bagian ahli waris yang terhijab. Dasar hukum kekerabatan sebagai ketentuan bahwa

27 Andi Syamsu Alam and M Fauzan, Hukum Pengangkatan Anak Perspektif Islam (Jakarta: Kencana Prenada Media Group, 2007), 219.

28 Ibid., 222.

${ }^{29}$ Muhammad Ali Al Shabuni, dalam bukunya al mawaris fi al syari'ah al-Islamiyah fi Dhau'al-kitab wa al-sunnah mengatakan " Sungguh keberadaan kaum perempuan sebelum datang sinar terang Islam, tidak diberi bagian warisan sama sekali, argumentasinya mereka tidak bisa dan tidak mampu berperang. Orang-orang arab mengatakan "bagaimana kami memberi bagian kepada orang yang tidak bisa mengendarai kuda, tidak bisa membawa pedang, dan tidak bisa memerangi musuh" Maka mereks menolak memberi mereka bagian warisan seperti halnya mereka menolak memberi bagian kepada anak-anak kecil". Muhammad Ali al Shabuni, al mawaris fi al-Syari'ah al-Islamiyah fi Dhau'al-Kitab wa alSunnah, Bairut: Alam al-Kutub,1399 H/ 1985 M, h. 19 
laki-laki dan perempuan punya hak yang sama dalam mewaris adalah sebagaimana firman Allah QS. An-nisa'/ 7 dan QS. Al- Anfal/ 75;

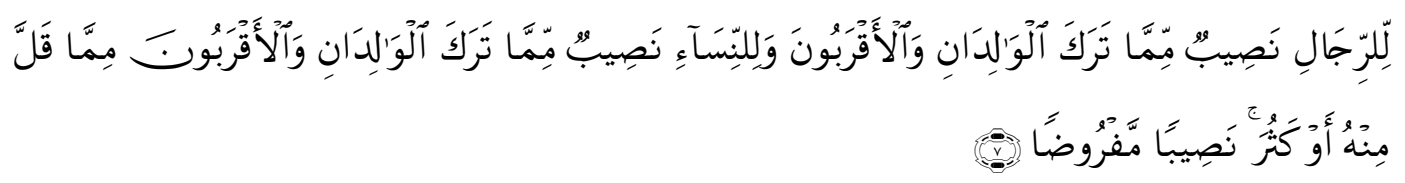

Terjemahnya:

"Bagi orang laki-laki ada hak bagian dari harta peninggalan ibu-bapak dan kerabatnya, dan bagi orang wanita ada hak bagian (pula) dari harta peninggalan ibu-bapa dan kerabatnya, baik sedikit atau banyak menurut bahagian yang telah ditetapkan".

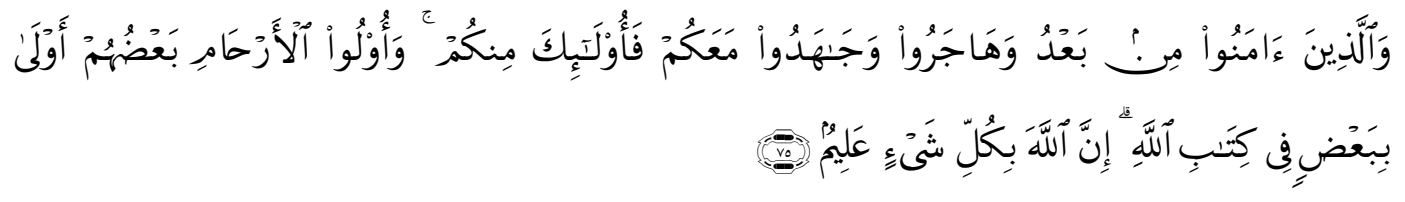

Terjemahnya:

"Dan orang-orang yang beriman sesudah itu kemudian berhijrah serta berjihad bersamamu Maka orang-orang itu termasuk golonganmu (juga). orang-orang yang mempunyai hubungan kerabat itu sebagiannya lebih berhak terhadap sesamanya (daripada yang bukan kerabat) di dalam kitab Allah. Sesungguhnya Allah Maha mengetahui segala sesuatu"

Kedua, Hubungan perkawinan atau semenda (al- musabarah). Perkawinan yang sah menyebabkan adanya hubungan hukum saling mewarisi antara suami dan istri. Perkawinan yang sah adalah perkawinan yang syarat dan rukunnya terpenuhi, baik menurut ketentuan hukum agama maupun ketentuan administratif sebagaimana diatur dalam perundangundangan yang berlaku. Pencatatan perkawinan sangat diperlukan untuk membuktikan secara yuridis formal, bahwa dua orang telah melakukan perkawinan. Sehingga dengan pencatatan tersebut bisa diketahui apakah hubungan perkawinan masih berlaku, apabila salah satu pihak ada yang meninggal dunia. Demikian juga untuk membuktikan kekerabatan anak-anak dari perkawinan itu, sebab jika tidak ada bukti yang tertulis ahli waris yang jauh menyangkal bahwa perkawinan itu tidak pernah ada, karena ingin menguasai harta warisan si mati. Tentu hal ini sangat merugikan pihak-pihak yang sebenarnya lebih berhak untuk mendapatkan warisan. Termasuk isteri dalam status perkawinan adalah ister-isteri yang dicerai raj'i, yaitu cerai yang dalam hal ini suami lebih berhak untuk merujuknya ketimbang orang lain, yaitu cerai pertama atau kedua, selama dalam masa tunggu (iddah ).

Ketiga, hubungan karena sebab memerdekakan budak atau hamba sahaya ( al- wala') atau karenaperjanjian tolong menolong, namun yang terakhir ini kurang mashur. ${ }^{30}$

${ }^{30} \mathrm{Al}$-wala' adalah hubungan kewarisan akibat seseorang memerdekan hamba sahaya, atau melalui perjanjian tolong menolong. Al- wala' yang pertama disebut wala' al-'ataqab atau 'ushubah ashabiyah, dan yang kedua disebut wala' al mawalah, yaitu wala' yang timbul akibat kesediaan seseorang untuk saling tolong menolong dengan yang lain melalui suatu perjanjian. 
Sedangkan menurut A. Hasan, sebab-sebab orang mendapatkan harta pusaka itu ada tiga macam, sebagai berikut :

a. Nasab, ialah perhubungan keluarga diantara mereka,

b. Nikah, ialah perkawinan seseorang dapat harta pusaka karena menjadi suami-isteri.

c. Wala' ialah hak mendapatkan harta pusaka karena memerdekakan hamba sahaya atau budak. ${ }^{31}$

Anak Angkat dalam kewarisan Islam bagi kalangan orang muslim, pengangkatan anak telah diatur dalam surat al-Ahzab Ayat ( 4-5 ). Sedangkan menurut Kompilasi Hukum Islam pasal 171 huruf ( h ) menyatakan :" anak angkat adalah anak yang dalam pemeliharaannya untuk hidupnya seharihari, biaya pendidikan, dan sebagainya beralih tanggungjawab dari orangtua asal kepada orang tua asal kepada orangtua angkatnya berdasarkan Putusan Pengadilan. ${ }^{32}$

Masalah pengangkatan anak bukanlah termasuk masalah baru di Indonesia. Sejak zaman dahulu telah dilakukan pengangkatan anak dengan cara dan motivasi yang berbeda-beda, sesuai dengan sistem hukum dan perasaan hukum yang hidup dan berkembang didaerah yang bersangkutan. Di Indonesia sendiri terdapat motivasi yang berbeda-beda.

Motivasi pengangkatan anak antara lain adalah untuk meneruskan keturunan, apabila dalam suatu perkawinan tidak memperoleh keturunan. ${ }^{33}$ Motivasi ini adalah salah satu jalan keluar dan alternatif manusia terhadap naluri kehadiran seorang anak dalam pelukan keluarganya setelah bertahuntahun tidak dikaruniai anak. Keluarga mempunyai peranan penting dalam kehidupan manusia sebagai makhluk sosial dan merupakan kelompok masyarakat terkecil yang terdiri dari ayah, ibu dan anak. Akan tetapi ketiga unsur belum tentu terpenuhi sehingga kadang-kadang terdapat suatu tidak mempunyai anak atau tidak mempunyai ibu. Dengan demikian dilihat dari segi eksistensi keluarga sebagai kelompok-kelompok kehidupan masyarakat, menyebabkan mereka menginginkan anak karena alasan yang demikian sehingga terjadilah perpindahan anak dari suatu kelompok keluarga yang lain.

Demikian antara lain beberapa motivasi pengangkatan anak yang dilakukan oleh orang-orang yang berkepentingan di Indonesia yang tersebar

${ }^{31}$ A Hasan, Al-Faraid (Surabaya: Pusaka Progresif, 1981), 6.

32 Himpunan Perundang-Undangan Dalam Lingkungan Pengadilan Agama, para. Menurut ketentuan hukum Islam anak angkat tidak mewaris, kemudian nilai pihak anak angkat adalah sosok yang mempunyai pertalian hubungan kemanusiaan yang bersifat khusus dalam soal kedekatan dan saling membantu serta penempatan statusnya dalam keluarga orang tau angkatnya sebagaimana layaknya keluarga sendiri. Dengan demikian anak angkat tidak termasuk golongan ahli waris, maka dengan sendirinya anak angkat tersebut tidak akan memperoleh harta warisan dari orang tua angkatnya yang telah meninggal terlebih dahulu. Oleh karena itu untuk melindungi hak-hak anak angkat dan orang tua angkat Kompilasi Hukum Islam memberi kepastian hukum berupa wasiat wajibah sebagaimana telah diatur dalam Pasal 209 KHI Ayat (1 dan 2).

33 W.A. Gerungan Dipl, Psych, Psikologi Sosial Suatu Ringkasan, 5th ed. (Jakarta: Eresco, 1977), 142.

PALITA: Journal of Social-Religi Research 
di masyarakat adat, sehingga adanya lembaga pengangkatan anak ini adalah merupakan kebutuhan masyarakat Indonesia.

\section{PENUTUP}

Berdasarkan uraian dari hasil pembahasan sebagaimana telah diuraikan pada bab-bab terdahulu, maka dapat ditarik suatu simpulan, yakni sebagai berikut :

1. Kedudukan anak angkat menurut Kompilasi Hukum Islam adalah tetap sebagai anak yang sah berdasarkan putusan pengadilan dengan tidak memutuskan hubungan nasab/darah dengan orang tua kandungnya, dikarenakan prinsip pengangkatan anak menurut Kompilasi Hukum Islam adalah merupakan manifestasi keimanan yang membawa misi kemanusiaan yang terwujud dalam bentuk memelihara orang lain sebagai anak dan bersifat pengasuhan anak dengan memelihara dalam pertumbuhan dan perkembangannya dengan mencukupi segala kebutuhannya.

2. KHI tidak mengakui adanya kedudukan anak angkat terhadap harta warisan dari orang tua angkat. Artinya anak angkat tidak berhak atas harta warisan orang tua angkat. Akan tetapi, dalam pasal 209 KHI menjelaskan bahwa keberadaan anak angkat mempunyai hak wasiat wajibah sebanyak-banyaknya 1/3 dari harta warisan orang tua angkat.

3. Ketentuan Hukum Islam, yakni :

a. Tidak memutuskan hubungan darah antara anak angkat dengan orang tua kandung.

b. Anak angkat tidak berkedudukan sebagai pewaris dari orang tua angkat, melainkan tetap sebagai pewaris dari orang tua kandungnya.

c. Orang tua angkat tidak dapat bertindak sebagai wali nikah dalam perkawinan terhadap anak angkatnya

\section{DAFTAR PUSTAKA}

A Hasan. Al-Faraid. Surabaya: Pusaka Progresif, 1981.

Abdurrahman. Kompilasi Hukum Islam Di Indonesia. Jakarta: Akademi Presindo, n.d.

Ahmad Rofiq. Hukum Islam Di Indonesia. Jakarta: Raja Grafindo Persada, 1995.

Andi Syamsu Alam, and M Fauzan. Hukum Pengangkatan Anak Perspektif Islam. Jakarta: Kencana Prenada Media Group, 2007.

AS Hornby, and EV Gatenbing. The Advencedn Learner's of Carent English. London: Oxford University, n.d.

Hazairin. Hukum Kewarisan Bilateral Menurut Al-Qur'an Dan Hadis. Jakarta: Tintamas, 1983. 
Hilman Hadikusuma. Hukum Waris Adat. Bandung: Citra Aditya Bakri, 1990.

Himpunan Perundang-Undangan Dalam Lingkungan Pengadilan Agama. Dirbinbapera Depag, 2001.

Iman Sudiyat. Hukum Adat Sketsa Asas. 2nd ed. Yogyakarta: Liberty, 1981.

M Budiarto. Pengangkatan Anak Ditinjau Dari Segi Hukum. Jakarta: Akademika Presindo, 1985.

Mahmud Yunus. Kamus Arab-Indonesia. Jakarta: Yayasan Penyelenggara Penterjemah atau penafsiran Al-Qur'an, 1973.

Marzuki Wahid, and Rumadi. Fiqh Mazhab Negara, Kritik Atas Hukum Islam Di Indonesia. 1st ed. Yogyakarta: LKIS, 2001.

Muderis Zaini. Adopsi Suatu Tinjauan Dari Tiga Sistem Hukum. Jakarta: Sinar Grafika, 1995.

Purwadarmita. Kamus Bahasa Indonesia. Jakarta: Balai Pustaka, 1976.

$\mathrm{R}$ Wirjono Projodikoro. Hukum Warisan Di Indonesia. Bandung: Sumur Bandung, 1980.

Soedaryo Soimin. Hukum Orang Dan Keluarga. Jakarta: Sinar Grafika, 1992.

Soeparman Usman. Ikhtisar Hukum Waris Kitab Undanng-Undang Hukum Perdata (Bw). Semarang: Darul Ulum Press, 1993.

Soerojo Wignjodipoero. Pengantar Dan Asas-Asas Hukum Adat. Jakarta: TP. Gunung Agung, 1995.

Soeroso R. Perbandingan Hukum Perdata. Jakarta: Sinar Grafika, 2001.

Sudarsono. Hukum Waris Dan Sistem Bilateral. Jakarta: Rineka Cipta, 1994.

W.A. Gerungan Dipl, Psych. Psikologi Sosial Suatu Ringkasan. 5th ed. Jakarta: Eresco, 1977.

Yan Pramadya Puspa. Kamus Hukum Belanda, Indoensia, Inggris. Semarang: Aneka, n.d. 